\title{
Role of Geography in the Relative Salience of the Antecedents of Cruise Passengers' Satisfaction
}

\author{
Amita Bhadauria $^{1}$, Amit Bhatnagar ${ }^{1} \&$ Sanjoy Ghose ${ }^{1}$ \\ ${ }^{1}$ Sheldon B. Lubar School of Business, University of Wisconsin, Milwaukee, USA \\ Correspondence: Amit Bhatnagar, School of Business Administration, University of Wisconsin-Milwaukee, P. O. \\ Box 742, WI 53201, USA. Tel: 1-414-229-3028. E-mail: amit@uwm.edu
}

Received: December 19, 2013

Accepted: January 2, $2014 \quad$ Online Published: March 24, 2014

doi:10.5539/ijms.v6n2p46

URL: http://dx.doi.org/10.5539/ijms.v6n2p46

\begin{abstract}
While it is quite straightforward to determine the factors that satisfy cruise passengers, such as dining, entertainment, etc., it is a challenge to determine their relative importance. A cruise firm with limited resources needs to concentrate its resources chiefly on those aspects of the cruise travel experience that its customers value more. Unfortunately the findings in the academic literature about the relative importance of the determinants of cruise passengers' satisfaction provide little guidance as they rarely converge across studies. We offer an explanation for this lack of convergence among the different studies about the relative importance of determinants. We believe that cruise customers who go to different locations form different market segments, with their own unique preferences. The differences in previous studies are due to the data being collected from different locations. We collect a unique dataset from an online website about cruise reviews, and use it to provide empirical support for our explanations. We find that while all consumers prefer value for money the most, the second most important factor is public rooms for tourists headed to Alsaka, cabins for the ones headed to Mediterranean, and service for the ones headed to Caribbean. The findings of this study would be of value to the management of cruise companies in refining advertising message, provision of different cruise services, etc.
\end{abstract}

Keywords: customer satisfaction, geographic segmentation, cruise industry, travel marketing, empirical analysis

\section{Introduction}

The cruise industry is one of the fastest growing and most lucrative segments of the tourism industry. The industry generated $\$ 42$ billion in gross output in the US in 2012, which increased by 2 billion from 2011 (CLIA, 2013). The average annual passenger growth rate has been $7.2 \%$ per annum since 1980 and the number of passengers has almost doubled in the past decade, from 8.6 million in 2002 to 17.2 million in 2012 (FCCA, 2012). Based on the growth trend, investment in the cruise industry is predicted to be more than $\$ 22$ billion between 2011 and 2015 (CLIA, 2013). The rapid growth in the cruise industry has been accompanied by growth in the competition among the cruise companies.

The fast growing cruise industry poses a challenge to the cruise lines and it has become crucial for them to build a loyal customer base to secure a favorable market share (Marti, 1991). Delivering a positive and satisfying overall experience is vital because attracting a new customer requires several times more capital than retaining an existing customer (Jones \& Sasser, 1995). Researchers have traditionally explored attributes such as dining, service, entertainment and food as antecedents of customer satisfaction for cruise passengers (Teye \& Leclerc, 1998, Qu \& Ping, 1999, Testa \& Sullivan, 2002, Hosany \& Witham, 2010). However, the current literature is not of much use to practitioners as findings from the literature rarely converge. Please see Table 1 where we have tabulated the findings from the four published papers. For instance, while according to Qu and Ping (1999) and Testa and Sullivan (2002), food and beverage is the second most important factor, for Teye and Leclerc (1998), it is the eight most important factor. 
Table 1. Prior research on the importance of ship attributes in customer satisfaction

\begin{tabular}{lllll}
\hline Order of importance & Teye \& Leclerc (1998) & Qu \& Ping (1999) & Testa \& Sullivan (2002) & Hosany \& Witham (2010) \\
\hline $\mathbf{1}$ & Cabin service & Crew performance & On board services & Ship aesthetics \\
$\mathbf{2}$ & Dining room service & Food \& beverage & Food \& Beverage & Entertainment \\
$\mathbf{3}$ & Cleanliness of ship & Entertainment & Lodging & Education level of cruisers \\
$\mathbf{4}$ & Cruise staff & Accommodation & Entertainment & Escapism \\
$\mathbf{5}$ & Entertainment & Other amenities & & \\
$\mathbf{6}$ & Bar service & & & \\
$\mathbf{7}$ & Ports of call & & & \\
$\mathbf{8}$ & Quality of food & & & \\
$\mathbf{9}$ & Purser staff/info desk & & & Hong-Kong, Cambodia, \\
$\mathbf{1 0}$ & Shore tours & & & Caribbean, \\
$\mathbf{P o r t s ~ o f ~ d e s t i n a t i o n ~}$ & Caribbean & Hong-Kong & Alaska, Western Mexico & Vietnd \\
& & & 9 & 1 \\
\hline
\end{tabular}

Analyzing the data from Table 1, we find that all these published studies collected data from a limited number of ships (number varying from 1 to 9 ) and from just a few locations. The cruise industry caters to a varied customer base, and hence the cruise companies need to appreciate and acknowledge the dissimilarities in their customers. It is apparent that in order to attract new customers, retain old customers, lure customers to switch and to be viewed as the most favourable ship, the cruise companies must customize and position their cruises according to the preferences of each market segment. There is a dearth of research on the cruise industry, in the area of market segmentation. Pertaining to the cruise industry, only a few studies using attributes have focused on segment level analysis (Petrick, 2003; Petrick \& Sirakaya, 2004; Petrick, 2011; Brida et al., 2012). However, none of these studies has used geographic region as a basis for market segmentation and we seek to fill this gap through our research. Careful analysis of Table 1 indicates that each one of the four papers collected data from only one region, and these regions are different for the four studies. Can it be that the variation existing in Table 1 is due to geography? This is the question that we intend to explore.

Past research has implicitly assumed that the impacts of the various antecedents of satisfaction do not vary across the geographic market of cruise passengers. We feel that this is unlikely to be the case in practice since the existence of geographic heterogeneity in consumer tastes is a well-documented phenomenon in travel industry (Gartner, 1996). Therefore in our present research we use quantitative models to study how the impacts of attributes might differ across the different geographic segments of the cruise market; and our findings have very clear managerial implications for the cruise industry. Specifically, our research aims at finding the relationship between attributes and customer satisfaction of different cruise passenger segments based on the most popular ports of destination. We investigate if the salience and relative importance of cruise ship attributes can be explained by geographical segmentation.

Our study has two very important managerial implications. This study can be used to refine the advertising message for different geographic regions, as well as to improve the cruise services. Firms try to attract new customers through marketing communications. The marketing message in these communications needs to be customized for specific groups to address their concerns better. Second, while providing different cruise services, managers need to limit their expenditures to only those services that are important to their target customers. Otherwise, cruises will not be cost effective. The services that are important to a customer will also depend on the segment to which a customer belongs. Demographic factors are not particularly suitable for segmenting the cruise market as unlike other products, such a perfumes, clothes, shoes, etc. which are purchased by individuals, cruise products are often bought by families and friends with substantial demographic variety. For instance, if families are purchasing cruise products, age and gender will not be suitable basis for segmentation, as families have members of different genders and ages. Therefore, we need new a basis for segmenting the cruise passengers.

We next review the past literature to put our paper in proper perspective. In section 3, we discuss the data and in section 4 , we discuss the results of our empirical analysis. In the last section, we discuss the managerial implications of this study.

\section{Literature Review}

In this section, we present academic research from three different fields. First, we review the literature on customer satisfaction in the cruise industry. We then study the different papers on market segmentation in the 
context of the cruise industry. Last, we review some papers that segment the cruise travel market on a geographical basis.

\subsection{Customer Satisfaction in the Cruise Industry}

In the context of the cruise industry, customer satisfaction is conventionally defined as the outcome of a comparison between the expectation of quality and the perception of delivery of service at various points on a cruise vacation (Zeithaml \& Parasuraman, 1994). Despite the rapid growth of the cruise industry, there has been limited research in the area of customer satisfaction of cruise passengers (Teye \& Leclerc, 1998). A number of research studies in the tourism section have shown that the overall satisfaction of tourists is primarily influenced by their assessment of the different attributes of the destinations for their visit. The repeat visit of the tourists to a destination primarily depends on their satisfaction with the destination, however, it is also related to the attributes of destinations. (Alegre \& Cladera, 2006; Baker \& Crompton, 2000; Crompton \& Love, 1995; Danaher \& Arweiler, 1996; Kozak, 2002; Kozak \& Rimmington, 1999; Murphy, Pritchard, \& Smith, 2000; Pizam \& Ellis, 1999; Yoon \& Uysal, 2005).

Teye and Leclerc (1998) examined passengers' satisfaction with product and service delivery aspects for North American cruise passengers. This study focused specifically on attributes that cruise passengers perceived as important to them. They conducted an exploratory study and collected data from passengers of two ships from the same cruise line. According to the results of this study, consumers evaluated the cruise line to have highest rating on cabin service followed by dining room service, cleanliness of ship, cruise staff, entertainment, bar service, ports of call, quality of food, purser staff/info desk and shore tours. A cruise ship ranking high on cabin service is valuable to cruise ship managers only if cabin service is an important antecedent of customer satisfaction. If it is not, then investment on improving customer service would be a waste. Therefore, we extend this study by linking cruise ship attributes to customer satisfaction, and furthermore showing that this relationship is moderated by the destination of the cruise ship.

Qu and Ping (1999) conducted a study to examine the cruise market in Hong Kong. They were interested in profiling the Hong Kong cruise travellers, understanding their motivation factors and satisfaction levels. This research was based on data collected from 330 passengers from five ships. Their results indicate that crew performance leads to the highest customer satisfaction followed by food and beverage, entertainment, accommodation and other amenities on the ship. The findings from the research of Testa \& Sullivan (2002) are similar to the findings of Qu \& Ping (1999). According to the research by Testa \& Sullivan (2002) on customer satisfaction and quality in the cruise industry, the overall experience of the cruise passengers outside of their accommodation had the highest influence on their perception of the cruise's quality. They also found that regardless of the ship size, the interaction between the crew and cruise passengers played an important role in the overall perception of the cruise. The findings of this research also indicated that food and beverages on a cruise contributed substantially to improving customer satisfaction. The findings of this research were based on a survey of cruise passengers of nine ships.

Hosany and Witham (2010) focused on identifying the most important antecedents of cruise passengers' satisfaction and investigating the relationship between cruise passengers' satisfaction and their intentions to recommend. According to their research, the aesthetic dimension which represents the physical aspects of a ship makes the maximum contribution to predicting memory, arousal, overall perceived quality, satisfaction and intention to recommend. Their findings clearly demonstrate that ship aesthetics is an important factor of the overall cruise experience. The entertainment dimension was the second most influential determinant of intention to recommend followed by the education level of cruise passengers, and escapism. This study demonstrated that ship aesthetics and entertainment on a cruise are the most significant contributors to customer satisfaction and their intention to recommend. The items in their study that were related to ship aesthetics were somewhat subjective and the data was collected from only one ship over a duration of two weeks. The variables in our research are objective and we identify customer preferences based on these objective measures. Also our sample is likely to be much more representative due to its size and diversity.

The past research in the field of customer satisfaction lacks diversity and good sample sizes. The majority of data for the prior papers was collected on a small number of ships through surveys or interviews. The data for our research is collected from as many as 271 cruise ships, which is much more likely to capture a representative sample compared to other such studies in the past. Prior studies collected data from only one geographic region. Our sample includes data from diverse ports of call and itineraries. Primarily, our research aims at finding the relationship between cruise attributes and satisfaction of cruise passengers, and the moderating role of geography. 


\subsection{Customer Segments in the Cruise Industry}

Segmentation of customers allows a marketer to deliver a product that matches the target audience's expectations and requirements (Pickton \& Broderick, 2005). Past research has focused on finding out the preferences of cruise passengers in general but there is little knowledge about the differences in their preferences. Our research aims at filling this gap by examining the differences in preferences of different cruise customers.

According to Marti (1991), market segmentation in the cruise industry is an essential prerequisite to attaining success and gaining market share. This article introduced the concept of a non-traditional port and focused on market segmentation in the cruise industry. The term non-traditional port refers to ports that are operational only on a seasonal or experimental basis - for example, ports other than Miami, Port Everglades or San Juan. The findings of this research indicate that geography is the most important factor that affects the attraction of cruise ship passengers to a non-traditional port, specifically cruisers prefer ports that are closer to their place of residence. An interesting finding of this study was that passengers' demographics and income were not useful in determining patronage of non-traditional ports.

Petrick (2003) focused on segmenting cruise passengers using the variable of price sensitivity. He wanted to examine if price-conscious customers are desirable. He found three segments of cruise customers based on price sensitivity; less sensitive, moderately sensitive, highly sensitive. The findings of this research show that less price sensitive customers are likely to spend more on a cruise and more price sensitive consumers are more likely to evaluate their cruise experiences positively. These results indicate that offering discounted cruises will attract passengers who are likely to spend less, but appreciate the cruise line more. Hence, they are likely to be repeat customers who can contribute to long-term success. These customers are easier to retain and evaluate cruise experience more positively and this results in the generation of positive word of mouth advertising. On the other hand, cruises without discounts may attract a more affluent customer segment; however, it may not be substantial enough to sustain long-term profitability. The findings of this study were based on data collected from two cruise ships.

Petrick and Sirakaya (2004) conducted a research to segment cruise passengers based on their loyalty. The results of this study suggest that loyal passengers are more satisfied with their past cruise experiences, have higher intentions of repeat cruising, perceive better value and are more likely to spread positive word of mouth. This study found that similar to loyal cruisers, first time cruisers who were satisfied with their cruise experience, were more attached, had higher perceived value and also more satisfied with the tangible and intangible services on the cruise. This study indicates that the traditional four-quadrant typology (spurious, latent, low, high) cannot be used to explain all tourist loyalty. However, understanding the differences between first time cruisers and repeat cruisers and the factors that impact their loyalty, have significant managerial implications.

Another study was conducted by Petrick (2011) to identify the segments of cruise passengers based on their perceptions of a cruise line's reputation. This research identified three segments of perception of cruise reputation; highest perception of reputation, moderate perception of reputation and low perception of reputation. The results of this research indicated that demographics had minimal effect on the perception of a cruise line's reputation. Also, reputation had a significant influence on a cruise passenger's perceptions of price sensitivity, monetary price, behavioural price, quality, value, satisfaction, word of mouth and repurchases intentions. The sample for this research was collected from two separate seven-day Caribbean voyages on the same ship.

Brida et al. (2012) aimed at segmenting cruise passengers visiting Uruguay, in their study. They sorted cruise passengers into clusters based on similarity in demographic features, expenditure patterns and overall perceptions of their vacation experience in Uruguay. Their research identified three segments of cruisers with different trip profiles; retirees, professionals and repeat visitors. Each of these segments was homogenous and different from the other two segments. The authors suggest different marketing strategies for each of these segments. The results of this study were limited to the descriptive level.

Krieger, Moskowitz and Rabino (2005) conducted a study to find out what consumers want from a cruise vacation. They performed a conjoint analysis to categorize cruise customers into four groups based on their preferences. They divided the customers into; sightseeing, self-absorbed, pamper-me and novel up to date, informal. This research created offerings to suit each of these groups based on the results of the conjoint analysis. Scenic views and sightseeing such as whale watching expeditions, beauty of the sea, and scenic views from the decks were some of the top most elements of a cruise vacation for the respondents. Value for money was also one of the top three attributes for the total panel of respondents.

Past research has segmented the cruise passenger market based on price sensitivity, loyalty, perception of cruise line's reputation, consumer demographics, and psychographics. In this research we segment consumers based on 
the geographic location of where the cruise takes place. There are four segments of cruises in our research based on the ports of destination, Mediterranean, Caribbean, Alaska and Canada \& New England.

\subsection{Geographic Segmentation in the Travel Industry}

Segmentation based on geography holds an important place in the tourism industry, since traveling is an integral part of this sector. Research relevant to travel destinations has mostly used resort, region, state and country for market segmentation (Fuller \& Matzler, 2008; Sarigollu \& Huang, 2005; Juwaheer, 2007; Kim \& Prideaux, 2005). Also, geographic segmentation in the majority of studies in tourism has been done on the basis of tourists' place of residence or origin (Gartner, 1996). In contrast, geographic segmentation in our study is based on the port of destination for cruise vacations.

A recent study by Yuksel et al. (2010), demonstrated that travelers form positive emotional and cognitive bonds with a destination which are likely to affect their critical assessment and loyalty, with respect to that destination. Taking a cue from this study, we extend the similar phenomenon to travel destinations of cruise vacations. Some studies have shown that the preferences of tourists change frequently with destinations (French, 1999; Manente \& Cerato, 1999; Pike, 2004) and this makes it critical for the companies to modify their product offerings based on customer preferences for destinations.

The cruise industry is characterized by product offerings that involve travel across the world to a variety of destinations. This implies that geographic segmentation is vital for this industry since travel destination is a primary factor that cruise passengers consider when they plan a vacation. We chose to segment cruise market based on the top cruise destinations because little effort has been made to segment the cruise market based on such variables.

\section{Data}

We collected data for this research from the website cruisecritic.com, which is a portal for the cruise industry. This portal provides in-depth information about all aspects related to cruises. This includes objective reviews of approximately 400 ships, profiles of more than 75 cruise lines, and over 250 worldwide ports. The portal also has details about different current promotions in the cruise industry.

Cruisecritic.com also serves as a platform for cruise passengers to share their post vacation experiences by contributing an online review. The reviewers rate their experience, on a scale of 1 to 5 , on a variety of cruise ships' attributes such as dining services, public rooms, cabins, entertainment, spa \& fitness, shore excursions, embarkation, overall service and value for money. These rankings are used as independent variables in this research. The reviewers also rate their overall satisfaction on a rating of 1 to 5 , and this is the dependent variable for our research.

Embarkation is the process of boarding a cruise ship at the start of a journey. It is the first process at the onset of a cruise vacation and can be a lengthy and tiresome one as it usually requires paperwork and security checks. The embarkation experience that cruise ship customers undergo can clearly influence overall cruise satisfaction. Food is one of the most integral part of any holiday and cruises are especially famous for their lavish and vast variety of cuisines. The variable dining services captures the experience of cruise passengers regarding food, dining rooms and service related to dining. Cruisers spend a considerable amount of time in their cabins depending on the geographic region and the weather, and this experience is rated under the variable, 'Cabins'. Cruise companies spend a lot of money on providing entertainment on board with events like Broadway shows, musical concerts, Cirque shows, magic shows, movie theaters, casinos, dance floors and masquerade balls (cruisecritic.com, 2013). Many cruise lines are famous for their entertainment and often customers choose them because of this. The cruise reviews rate entertainment experience on board under the variable, 'Entertainment'. The variable 'Public rooms' refers to the common areas on a cruise ship such as the reception, lounges and other areas for socializing. Spa \& Fitness facilities are a part of the luxurious amenities on a cruise vacation and comprise of ethnic massages, wraps, and other beauty treatments. Cruises also have access to fully equipped fitness and tanning facilities on board and cruisers can rate them under, 'Spa \& Fitness'. Shore excursion is one of the most exciting features of a cruise ship since this enables passengers to explore various facets of ports of call like snorkeling through coral reefs, exploring local monuments, hiking on glaciers and shopping at local outdoor markets. Cruise lines generally offer this service at an additional price and the service includes guided bus tours, sightseeing, cultural events, shopping etc. The variable 'Value for Money' captures the experience of cruise customers in terms of whether they think they got their money's worth. Cruise ships are well known for providing impeccable and excellent service on board and the variable, Service, captures this aspect of the cruise customers' experience. 
We collected 400 separate passenger reviews of cruise ships. We limited our data collection to 19 cruise ships of one of the leading cruise lines that operates globally. There are several different types of cruise lines and each line targets a different customer segment. We limited our data collection to the ships of only one cruise lines to ensure that all passengers are from the same market segment. All the cruise ships of this line have similar characteristics, and any variation due to ship characteristics is also minimized. This precaution was taken to isolate the effect of geography and remove all obvious sources of variation.

We collected reviews from cruise vacations from four different geographic regions, namely Alaska, Mediterranean, Caribbean and Canada \& New England. We collected 100 reviews from each geographic region, and obtained a total of 400 reviews. The reviews for each region were picked at random.

\section{Results}

We are specifically interested in learning how the importance of the different cruise attributes vary with region. We employ multiple regression models to examine the influence of cruise ship attributes on overall customer satisfaction. The different cruise ship attributes that were considered in this study are Dining, Public Rooms, Cabins, Entertainment, Spa and Fitness, Shore Excursions, Embarkation, Service, and Value for Money. This was done separately for each geographic region. The results allow us to identify the important cruise attribute for each geographic regions. To determine the relative salience of the attributes, we calculate the standardized coefficients.

We first tested the data for multicolleanrity by determining the VIF (variance inflation factor) values. We report these values in Table 2.

Table 2. Variance inflation factors

\begin{tabular}{llllll}
\hline \multirow{2}{*}{$\begin{array}{l}\text { Cruise ship } \\
\text { attributes }\end{array}$} & VIFs & \multicolumn{3}{l}{} \\
\cline { 2 - 6 } & Alaska & Canada \& New England & Caribbean & Mediterranean & All Segments Together \\
\hline Dining & 2.55 & 2.17 & 3.31 & 1.90 & 2.04 \\
Public Rooms & 2.53 & 2.64 & 1.80 & 2.89 & 2.05 \\
Cabins & 2.07 & 1.26 & 1.84 & 2.01 & 1.52 \\
Entertainment & 2.67 & 1.40 & 2.33 & 1.60 & 1.67 \\
Spa \& Fitness & 1.89 & 1.99 & 2.28 & 1.32 & 1.55 \\
Shore Excursions & 1.61 & 1.33 & 1.18 & 1.54 & 1.25 \\
Embarkation & 1.26 & 1.35 & 1.65 & 1.37 & 1.24 \\
Service & 1.85 & 2.44 & 2.69 & 2.42 & 2.15 \\
Value for money & 2.11 & 2.77 & 3.43 & 2.16 & 2.20 \\
\hline
\end{tabular}

As can be seen in Table 2, all the values of VIF are low. The maximum value of VIF is for Value for money for Caribbean segment, which is 3.43 . Since all these values are small, we can conclude that the problem of multicollinearity is not significant for our data, and proceed with further processing of the data.

We first discuss the results for the participants who took cruises in Alaska region. The results of the regression analysis are presented in Table 3 .

Table 3. Cruise attributes preferences for Alaska region

\begin{tabular}{|c|c|c|c|c|c|}
\hline Ship Attributes & $\begin{array}{l}\text { Unstandardized } \\
\text { Coefficients }\end{array}$ & $\begin{array}{l}\text { Standard } \\
\text { Error }\end{array}$ & $\begin{array}{l}\text { Standardized } \\
\text { Coefficients } \\
\end{array}$ & t Statistics & p value \\
\hline Constant & -0.925 & 0.419 & & -2.21 & 0.03 \\
\hline Dining & 0.112 & 0.061 & 0.143 & 1.83 & 0.07 \\
\hline Public rooms & 0.239 & 0.088 & $0.192 *$ & 2.73 & 0.01 \\
\hline Cabins & 0.178 & 0.081 & $0.133 *$ & 2.19 & 0.03 \\
\hline Entertainment & 0.023 & 0.062 & 0.028 & 0.36 & 0.72 \\
\hline Spa \& Fitness & 0.042 & 0.084 & 0.033 & 0.50 & 0.62 \\
\hline Shore Excursions & 0.134 & 0.061 & $0.132 *$ & 2.20 & 0.03 \\
\hline Embarkation & 0.060 & 0.060 & 0.056 & 0.999 & 0.32 \\
\hline Service & 0.044 & 0.072 & 0.042 & 0.60 & 0.55 \\
\hline Value for money & 0.401 & 0.067 & $0.442 *$ & 6.02 & 0.00 \\
\hline
\end{tabular}

Note. *Significant at 0.05 level; R sq is 0.774 ; Adjusted R sq is 0.752 ; F Stats is 34.318 . 
The R square is very high. It has a value of 0.774 , which indicates that $77 \%$ of the variation in the dependent variables is explained by the independent variables. The F stats (34.318) is also quite high which indicates that the model fits the data. The most important factor for cruise passengers going to Alaska is value for money. The next important factor for them is for public rooms. This is followed by almost equal preference for cabins and shore excursions. These preferences can be explained by the fact that they spend a lot of time indoors in their cabin and in public rooms because of the cold weather. Alaskan cruises are famous for the magnificent glacial tours and exciting experiences such as dog sled rides on snow, whale watching and ice field excursion, which are unique attractions compared to other destinations and this explains significance of shore excursions for customers going on Alaskan cruises. They do not care much for dining, entertainment, spa \& fitness, embarkation and service. Therefore managers of cruise ships plying the Alaskan route should focus most on providing value for money. This should be followed by focus on public rooms, cabins and shore excursions.

We next discuss the results of regression analysis of customer preference data for cruises travelling to Mediterranean regions (Please see Table 4).

Table 4. Cruise attributes preferences for Mediterranean region

\begin{tabular}{llllll}
\hline Ship Attributes & $\begin{array}{l}\text { Unstandardized } \\
\text { Coefficients }\end{array}$ & Standard Error & $\begin{array}{l}\text { Standardized } \\
\text { Coefficients }\end{array}$ & t Statistics & p value \\
\hline Constant & -1.490 & 0.309 & & -4.82 & 0.00 \\
Dining & 0.140 & 0.061 & $0.133^{*}$ & 2.30 & 0.02 \\
Public rooms & 0.095 & 0.080 & 0.078 & 1.19 & 0.24 \\
Cabins & 0.318 & 0.061 & $0.266^{*}$ & 5.23 & 0.00 \\
Entertainment & 0.099 & 0.055 & 0.092 & 1.79 & 0.08 \\
Spa \& Fitness & 0.170 & 0.054 & $0.146^{*}$ & 3.13 & 0.00 \\
Shore Excursions & -0.018 & 0.049 & -0.018 & -.36 & 0.72 \\
Embarkation & -0.070 & 0.053 & -0.063 & -1.32 & 0.19 \\
Service & 0.153 & 0.068 & $0.144^{*}$ & 2.26 & 0.03 \\
Value for money & 0.474 & 0.061 & $0.458^{*}$ & 7.80 & 0.00 \\
\hline
\end{tabular}

Note. *Significant at 0.05 level; $\mathrm{R}$ sq is 0.852 ; Adjusted R sq is 0.837 ; F Stats is 57.626 .

The $\mathrm{R}$ square at 0.852 is very high, as $85 \%$ of the variation in the dependent variable is explained by the antecedents. The F stats (57.626) indicates a good model fit. Interestingly, these passengers also consider value for money as the most important aspect while choosing a cruise vacation. For these passengers, the next most important factor is cabins. This is followed by spa \& fitness, service and dining. These passengers do not care much for public rooms, entertainment, shore excursions, and embarkation.

In Table 5, we present the results of regression analysis for passengers travelling to Caribbean ports.

Table 5. Cruise attributes preferences for Caribbean region

\begin{tabular}{llllll}
\hline Ship Physical Aspects & $\begin{array}{l}\text { Unstandardized } \\
\text { Coefficients }\end{array}$ & Standard Error & $\begin{array}{l}\text { Standardized } \\
\text { Coefficients }\end{array}$ & t Statistics & p value \\
\hline Constant & -0.714 & 0.330 & & -2.17 & 0.03 \\
Dining & 0.121 & 0.065 & 0.134 & 1.88 & 0.06 \\
Public rooms & 0.128 & 0.070 & 0.101 & 0.76 & 0.07 \\
Cabins & 0.055 & 0.072 & 0.044 & 0.46 & 0.45 \\
Entertainment & 0.027 & 0.059 & 0.028 & 0.08 & 0.65 \\
Spa \& Fitness & 0.006 & 0.075 & 0.005 & 0.59 & 0.94 \\
Shore Excursions & 0.034 & 0.057 & 0.028 & 1.18 & 0.56 \\
Embarkation & 0.063 & 0.054 & 0.064 & 1.99 & 0.24 \\
Service & 0.152 & 0.076 & $0.138^{*}$ & 0.05 \\
Value for money & 0.574 & 0.075 & $0.567 *$ & 7.63 & 0.00 \\
\hline
\end{tabular}

Note. *Significant at 0.05 level; R sq is 0.828 ; Adjusted R sq is 0.811 ; F Stats is 49.766 . 
The $\mathrm{R}$ square is 0.828 , implying that $83 \%$ of the variation in the dependent variable is explained by the independent variables. The F-stats is $\mathbf{4 8 . 7 6 6}$ which indicates a good model fit. For these passengers, value for money is the most important factor influencing satisfaction and service is the second most important factor. Interestingly, none of the other factors influence customer satisfaction.

The results of our regression analysis for cruise ships going to Canada and New England are presented in Table 6.

Table 6. Cruise attributes preferences for Canada and New England region

\begin{tabular}{|c|c|c|c|c|c|}
\hline Physical & $\begin{array}{l}\text { Unstandardized } \\
\text { Coefficients }\end{array}$ & Standard Error & $\begin{array}{l}\text { Standardized } \\
\text { Coefficients }\end{array}$ & t Statistics & p value \\
\hline Constant & -0.575 & 0.351 & & -1.64 & 0.10 \\
\hline Dining & 0.096 & 0.056 & 0.111 & 1.71 & 0.09 \\
\hline Public rooms & -0.033 & 0.094 & -0.026 & -0.35 & 0.72 \\
\hline Cabins & 0.051 & 0.07 & 0.039 & 0.73 & 0.47 \\
\hline Entertainment & 0.175 & 0.051 & $0.193 *$ & 3.43 & 0.00 \\
\hline Spa \& Fitness & 0.139 & 0.067 & $0.14 *$ & 2.07 & 0.04 \\
\hline Shore Excursions & 0.02 & 0.054 & 0.02 & 0.37 & 0.71 \\
\hline Embarkation & 0.116 & 0.046 & $0.134 *$ & 2.49 & 0.02 \\
\hline Service & 0.12 & 0.069 & 0.128 & 1.75 & 0.08 \\
\hline Value for money & 0.467 & 0.077 & $0.471 *$ & 6.05 & 0.00 \\
\hline
\end{tabular}

Note. *Significant at 0.05 level; R sq is 0.799 ; Adjusted R sq is 0.799 ; F Stats is 39.708 .

The R square value of 0.799 is quite high as $89 \%$ of the variation in the customer satisfaction data is explained by the independent variables. The F statistics is also high and indicates a good model fit. For these passengers, the most important antecedent is value for money. This is followed by entertainment, spa \& fitness and embarkation. None of the other factors seem to play a role in customer satisfaction.

\section{Discussions and Conclusions}

We compare the four geographic segments in terms of the relative salience of the factors that influence customer satisfaction and present the results in Table 7.

Table 7. Cruise ship attributes preferences for the four regions

\begin{tabular}{lllll}
\hline Order of importance & Alaska & Mediterranean & Caribbean & $\begin{array}{l}\text { Canada and New } \\
\text { England }\end{array}$ \\
\hline 1 & Value for money & Value for money & Value for money & Value for money \\
2 & Public Rooms & Cabins & Service & Entertainment \\
3 & Cabins & Spa \& Fitness & & Spa \& Fitness \\
4 & Shore Excursions & Service & & Embarkation \\
\hline
\end{tabular}

Our research suggests that value for money is the most significant aspect of a cruise vacation for all cruise passengers regardless of the geographic segment. However, after value for money, the importance of a cruise attribute depends on the destination of cruise ships. For instance, cruise passengers travelling to both the Mediterranean and the Caribbean value service. The difference is that while for Caribbean passengers it is the second most important criterion, for Mediterranean passengers, it is the fourth most important criterion. Cruisers to Alaska region view cabin as an important aspect of a cruise. Spa \& fitness amenities on board are attractive to cruisers sailing to Mediterranean and Canada and New England. Embarkation and entertainment had significant influence on the preference of Canada and New England cruisers and Alaskan cruisers gave importance to Public rooms and Shore excursions.

We expected that the preferences of cruise ship customers will vary with different geographic segments and our results confirm this. The managerial implications of our study are clear and quite important to the managers of cruise ships. Our study provides managers with the information that can help them to customize their cruises according to the geographic area where the ship is sailing. 
This study can be extended in a number of ways. The R square is quite high for all the four segments, but is still not $100 \%$. This indicates that there are some other independent variables that are not included in our study. Future researchers need to do some focus group interview with potential passengers and try to find some other factors that influence customer satisfaction. We also did not include information on demographics, as this data was not available to us. Different demographic segments could have different needs and their satisfaction thus could be influenced by different factors.

Overall though, our study has two very important managerial implications. This study can be used to refine the advertising message for different geographic regions, as well as to improve the cruise services. An important strategic issue in global marketing is whether the managers of a firm should use standardized message in all their marketing communications or customize the message for different geographic regions. Managers tend to prefer the former as it is a more cost-effective approach. Our study would recommend the second as consumer needs are different in different geographic areas. Furthermore, our study identifies the issues that need to be highlighted in advertising message in different regions.

Our study indicates that the value for money is the most important attribute for the customers of this cruise company. Therefore managers need to be very mindful of the cost of running a cruise ship and look for savings wherever possible. Provision of different cruise services costs different levels of expenditures. A firm should not try to improve its performance on all attributes, as that would be very expensive to execute and thereby have negative impact on the 'value for money' factor. Therefore, managers would like to focus on only a subset of attributes that are really important to their target customers. Our study provides direction on this issue. We highlight the features that are most important to cruise passengers in different regions. Ideally managers should focus on only these issues.

\section{References}

Alegre, J., \& Cladera, M. (2006). Repeat visitation in mature sun and sand holiday destinations. Journal of Travel Research, 44(3), 288-297. http://dx.doi.org/10.1177/0047287505279005

Baker, D. A., \& Crompton, J. L. (2000). Quality, satisfaction and behavioral intentions. Annals of Tourism Research, 27(3), 785-804. http://dx.doi.org/10.1016/S0160-7383(99)00108-5

Bieger, T., \& Laesser, C. (2002). Market segmentation by motivation: The case of Switzerland. Journal of Travel Research, 41(1), 68-76. http://dx.doi.org/10.1177/004728750204100110

Bojanic, D. C., \& Warnick, R. B. (1996). Segmenting the market for winter vacations. Journal of Travel \& Tourism Marketing, 4(4), 85-95. http://dx.doi.org/10.1300/J073v04n04_07

Brida, J. G., Scuderi, R., \& Seijas, M. N. (2012). Segmenting Cruise Passengers Visiting Uruguay: a Factor-Cluster Analysis. International Journal of Tourism Research.

Charlier, J. J., \& McCalla, R. J. (2006). A geographical overview of the world cruise market and its seasonal complementarities. Cruise Ship Tourism, 18-30. http://dx.doi.org/10.1079/9781845930486.0018

Chow, H. S., Lau, V. P., Lo, W. C., Sha, Z., \& Yun, H. (2007). Service quality in restaurant operations in China: decision-and experiential-oriented perspectives. International Journal of Hospitality Management, 26(3), 698-710. http://dx.doi.org/10.1016/j.ijhm.2006.07.001

CLIA. (n.d.). Retrieved from http://www.cruising.org/regulatory/industry-welcome

CLIA. (n.d.). Retrieved from http://www.cruising.org/regulatory/issues-facts

CLIA. (n.d.). Retrieved from http://www.cruising.org/sites/default/files/pressroom/January30Deck_FINAL.pdf

Conlon, D. E., Van Dyne, L., Milner, M., \& Ng, K. Y. (2004). The effects of physical and social context on evaluations of captive, intensive service relationships. Academy of Management Journal, 47(3), 433-445.

Crompton, J. L., \& Love, L. L. (1995). The predictive validity of alternative approaches to evaluating quality of a festival. Journal of Travel Research, 34(1), 11-24. http://dx.doi.org/10.2307/20159592

Cronin, Jr. J. J., \& Taylor, S. A. (1992). Measuring service quality: a reexamination and extension. Journal of Marketing, 56(3), 55-68. http://dx.doi.org/10.2307/1252296

Crouch, G. I., Oppewal, H., Huybers, T., Dolnicar, S., Louviere, J. J., \& Devinney, T. (2007). Discretionary expenditure and tourism consumption: Insights from a choice experiment. Journal of Travel Research, 45(3), 247-258. http://dx.doi.org/10.1177/0047287506295912 
Danaher, P. J., \& Arweiler, N. (1996). Customer Satisfaction in the Tourist Industry A Case Study of Visitors to New Zealand. Journal of Travel Research, 35(1), 89-93. http://dx.doi.org/10.1177/004728759603500113

Davis, B. D., Pysarchik, D. T., Chappelle, D. E., \& Sternquist, B. J. (1993). Tourism market segmentation in Michigan's Upper Peninsula: a regional approach. Journal of Travel \& Tourism Marketing, 2(1), 1-30.

Dodd, T., \& Bigotte, V. (1997). Perceptual Differences Among Visitor Groups to Wineries. Journal of Travel Research, 35(3), 46-51. http://dx.doi.org/10.1177/004728759703500307

Dolnicar, S., \& Laesser, C. (2007). Travel agency marketing strategy: insights from Switzerland. Journal of Travel Research, 46(2), 133-146. http://dx.doi.org/10.1177/0047287507299573

Dube, L., Renaghan, L. M., \& Miller, J. M. (1994). Measuring customer satisfaction for strategic management. The Cornell Hotel and Restaurant. Administration Quarterly, 35(1), 39-47. http://dx.doi.org/10.1016/0010-8804(94)90063-9

FCCA. (n.d.). Retrieved from http://www.f-cca.com/downloads/2012-Cruise-Industry-Overview-Statistics.pdf

French, Y. (1999). The Communication and PR Strategies for Mature Destinations Repositioning Themselves in The Market. In Manente, M., \& Cerato, M. (Eds.), From Destination to Destination Marketing and Management-Designing and Repositioning Tourism Products (pp. 49-57). CISET/University of Venice Press, Venezia.

Füller, J., \& Matzler, K. (2008). Customer delight and market segmentation: An application of the three-factor theory of customer satisfaction on life style groups. Tourism Management, 29(1), 116-126.

Gartner, W. C., \& Gartner, W. (1996). Tourism development: Principles, processes, and policies (pp. 110-112). New York: Van Nostrand Reinhold. http://dx.doi.org/10.1016/j.tourman.2007.03.021

Gibson, P. (2006). Cruise operations management. Elsevier.

Gladwell, N. J. (1990). A psychographic and sociodemographic analysis of state park inn users. Journal of Travel Research, 28(4), 15-20. http://dx.doi.org/10.1177/004728759002800404

Hosany, S., \& Witham, M. (2010). Dimensions of cruisers' experiences, satisfaction, and intention to recommend. Journal of Travel Research, 49(3), 351-364.

Hosany, S., Ekinci, Y., \& Uysal, M. (2006). Destination image and destination personality: An application of branding theories to tourism places. Journal of Business Research, 59(5), 638-642. http://dx.doi.org/10.1016/j.jbusres.2006.01.001

Hung, K., \& Petrick, J. F. (2011). Why do you cruise? Exploring the motivations for taking cruise holidays, and the construction of a cruising motivation scale. Tourism Management, 32(2), 386-393. http://dx.doi.org/10.1016/j.tourman.2010.03.008

Johns, N., \& Gyimóthy, S. (2002). Market segmentation and the prediction of tourist behavior: the case of Bornholm, Denmark. Journal of Travel Research, 40(3), 316-327. http://dx.doi.org/10.1061/(ASCE)0742-597X(1996)12:6(11.2)

Jones, T. O., \& Sasser, W. E. (1995). Why satisfied customers defect. Harvard Business Review, 73(6), 88.

Juwaheer, T. D. (2007). Using service quality expectations as a criterion to segment international tourists in the hospitality industry: An outlook of hotels of Mauritius. Journal of Travel \& Tourism Marketing, 21(2-3), 1-18. http://dx.doi.org/10.1300/J073v21n02_01

Kim, S. S., \& Prideaux, B. (2005). Marketing implications arising from a comparative study of international pleasure tourist motivations and other travel-related characteristics of visitors to Korea. Tourism Management, 26(3), 347-357. http://dx.doi.org/10.1016/j.tourman.2003.09.022

Kolb, B. (2006). Tourism marketing for cities and towns (Vol. 10). Routledge. http://dx.doi.org/10.1016/B978-0-7506-7945-9.50003-0

Kotler, P. J., \& Armstrong, G. M. (2010). Principles of Marketing. Pearson Education.

Kozak, M. (2002). Comparative analysis of tourist motivations by nationality and destinations. Tourism Management, 23(3), 221-232. http://dx.doi.org/10.1016/S0261-5177(01)00090-5

Kozak, M., \& Rimmington, M. (1999). Measuring tourist destination competitiveness: conceptual considerations and empirical findings. International Journal of Hospitality Management, 18(3), 273-283. http://dx.doi.org/10.1016/S0278-4319(99)00034-1 
Krieger, B., Moskowitz, H., \& Rabino, S. (2005). What customers want from a cruise vacation: Using internet-enabled conjoint analysis to understand the customer's mind. Journal of Hospitality \& Leisure Marketing, 13(1), 83-111.

Lee, H., Lee, Y., \& Yoo, D. (2000). The determinants of perceived service quality and its relationship with satisfaction. Journal of Services Marketing, 14(3), 217-231. http://dx.doi.org/10.1108/08876040010327220

Loker, L. E., \& Perdue, R. R. (1992). A benefit-based segmentation of a nonresident summer travel market. Journal of Travel Research, 31(1), 30-35. http://dx.doi.org/10.1177/004728759203100107

Manente, M., \& Cerato, M. (1999). Destination Management: The Conceptual Framework. In M. Manente \& M. Cerato (Eds.), From Destination to Destination Marketing and Management-Designing and Repositioning Tourism Products (pp. 15-28). CISET/University of Venice Press, Venezia. http://dx.doi.org/10.1108/16605371111175302

Marti, B. E. (1991). Cruise ship market segmentation: a 'non-traditional'port case study. Maritime Policy \& Management, 18(2), 93-103. http://dx.doi.org/10.1080/03088839100000033

Mazanec, J. A. (1992). Classifying tourists into market segments: a neural network approach. Journal of Travel \& Tourism Marketing, 1(1), 39-60. http://dx.doi.org/10.1300/J073v01n01_04

Morrison, A. M., Hsieh, S., \& O'leary, J. T. (1994). Segmenting the Australian domestic travel market by holiday activity participation. Journal of Tourism Studies, 5(1), 39-56.

Moscardo, G., Pearce, P., \& Morrison, A. (2001). Evaluating different bases for market segmentation: A comparison of geographic origin versus activity participation for generating tourist market segments. Journal of Travel \& Tourism Marketing, 10(1), 29-49. http://dx.doi.org/10.1300/J073v10n01_03

Murphy, P., Pritchard, M. P., \& Smith, B. (2000). The destination product and its impact on traveller perceptions. Tourism Management, 21(1), 43-52. http://dx.doi.org/10.1016/S0261-5177(99)00080-1

Obenour, W., Lengfelder, J., \& Groves, D. (2005). The development of a destination through the image assessment of six geographic markets. Journal of Vacation Marketing, 11(2), 107-119. http://dx.doi.org/10.1177/1356766705052569

Parasuraman, A., Zeithaml, V. A., \& Berry, L. L. (1994). Reassessment of expectations as a comparison standard in measuring service quality: implications for further research. Journal of Marketing, 58(1), 111-124. http://dx.doi.org/10.2307/1252255

Petrick, J. F. (2003). Measuring cruise passengers perceived value. Tourism Analysis, 7(3-4), 34.

Petrick, J. F. (2005). Segmenting cruise passengers with price sensitivity. Tourism Management, 26(5), 753-762. http://dx.doi.org/10.1016/j.tourman.2004.03.015

Petrick, J. F., \& Sirakaya, E. (2004). Segmenting cruisers by loyalty. Annals of Tourism Research, 31(2), 472-475. http://dx.doi.org/10.1016/j.annals.2003.12.009

Pickton, D., \& Broderick, A. (2001) Integrated Marketing Communications. Pearson Education. http://dx.doi.org/10.4135/9781452229669.n1692

Pike, S. (2002). ToMA as a measure of competitive advantage for short break holiday destinations. Journal of Tourism Studies, 13(1), 9-19.

Pike, S., \& Ryan, C. (2004). Destination positioning analysis through a comparison of cognitive, affective, and conative perceptions. Journal of Travel Research, 42(4), 333-342. http://dx.doi.org/10.1177/0047287504263029

Pizam, A., \& Ellis, T. (1999). Customer satisfaction and its measurement in hospitality enterprises. International Journal of Contemporary Hospitality Management, 11(7), 326-339. http://dx.doi.org/10.1108/09596119910293231

Qu, H., \& Ping, E. W. Y. (1999). A service performance model of Hong Kong cruise travelers' motivation factors and satisfaction. Tourism Management, 20(2), 237-244. http://dx.doi.org/10.1016/S0261-5177(98)00073-9

Reid, L. J., \& Reid, S. D. (1997). Traveler geographic origin and market segmentation for small island nations: the Barbados case. Journal of Travel \& Tourism Marketing, 6(3-4), 5-21. http://dx.doi.org/10.1300/J073v06n03_02

Sanburn, J. (2013). Cruise Control. Time, 181(22), 22. 
Sarigollu, E., \& Huang, R. (2005). Benefits Segmentation of Visitors to Latin America. Journal of Travel Research, 43(3), 277-93. http://dx.doi.org/10.1177/0047287504272032

Swain, R. A., \& Barth, J. E. (2002). An analysis of cruise ship rating guides. International Journal of Hospitality \& Tourism Administration, 3(4), 43-60.

Testa, M. R., \& Sullivan, K. (2002). Customer Satisfaction, Quality in Cruise Industry. Hospitality Review, 20(2), $1-12$.

Teye, V. B., \& Leclerc, D. (1998). Product and service delivery satisfaction among North American cruise passengers. Tourism Management, 19(2), 153-160. http://dx.doi.org/10.1016/S0261-5177(97)00107-6

Tkaczynski, A., Hastings, K., \& Beaumont, N. (2006, December). Factors influencing repositioning of a tourism destination. Proceedings of the 2006 Australian and New Zealand Marketing Academy Conference (ANZMAC 2006). Queensland University of Technology, School of Advertising, Marketing and Public Relations.

Yoon, Y., \& Uysal, M. (2005). An examination of the effects of motivation and satisfaction on destination loyalty: a structural model. Tourism Management, 26(1), 45-56. http://dx.doi.org/10.1016/j.tourman.2003.08.016

Zeithaml, V. A., \& Parasuraman, A. (1994). Reassessment of expectations as a comparison standard in measuring service quality: Implications. Journal of Marketing, 58(1), 111-124. http://dx.doi.org/10.2307/1252255

\section{Copyrights}

Copyright for this article is retained by the author(s), with first publication rights granted to the journal.

This is an open-access article distributed under the terms and conditions of the Creative Commons Attribution license (http://creativecommons.org/licenses/by/3.0/). 